Article

\title{
Facile in-situ synthesis and deposition of monodisperse palladium nanoparticles on polydopamine-functionalized silica gel as a heterogeneous and recyclable nanocatalyst for aerobic oxidation of alcohols
}

\author{
Hojat Veisi *, Ahmad Nikseresht, Shahin Mohammadi, Saba Hemmati \\ Department of Chemistry, Payame Noor University, Tehran, Iran
}

\section{A R T I C L E I N F O}

\section{Article history:}

Received 29 December 2017

Accepted 21 February 2018

Published 5 June 2018

\section{Keywords:}

Silica

Polydopamine

Palladium nanoparticle

Oxidation

Alcohol

\begin{abstract}
A B S T R A C T
This paper describes a facile in-situ synthesis of palladium nanoparticles (Pd NPs) on silica gel/polydopamine composite $\left(\mathrm{SiO}_{2} / \mathrm{PDA}\right)$ without any stabilizer or reducing agent. In this approach, palladium ions were adsorbed on $\mathrm{SiO}_{2} / \mathrm{PDA}$ surfaces by immersing the $\mathrm{PDA}$-coated $\mathrm{SiO}_{2}$ particles in a palladium plating bath. Then, they were reduced in situ to Pd nanoclusters by the reducing ability of PDA's N-containing groups. The structure, morphology, and physicochemical properties of the synthesized nanocomposites were characterized by different analytical techniques such as high-resolution transmission electron microscopy, field-emission scanning electron microscopy, energy-dispersive X-ray spectroscopy, X-ray diffraction analysis, X-ray photoelectron spectroscopy, inductively coupled plasma and Fourier-transform infrared spectroscopy. The Pd NPs capped by the PDA groups had a strikingly small size $(30-40 \mathrm{~nm}) . \mathrm{SiO}_{2} / \mathrm{PDA} / \mathrm{Pd} \mathrm{NPs}$ exhibited high catalytic activity as a recyclable nanocatalyst in the aerobic oxidation of alcohols. Furthermore, recovery and multiple reuse of the catalyst revealed no detectable activity loss.
\end{abstract}

(c) 2018, Dalian Institute of Chemical Physics, Chinese Academy of Sciences. Published by Elsevier B.V. All rights reserved.

\section{Introduction}

One of the most important transformations in synthetic organic chemistry is oxidation of alcohols to their corresponding carbonyl compounds [1,2]. Researchers have attempted to use transition-metal-catalyzed aerobic oxidation reactions as an economic and environmentally friendly approach to carry out this transformation [3,4]. Oxygen utilized in aerobic oxidation has considerable advantages in that molecular oxygen is inexpensive and its only byproduct is water. Therefore, extensive catalytic studies on finding efficient active metals for aerobic homo- and heterogeneous catalytic oxidation, e.g. Fe [5], Ru [6], Co [7], $\mathrm{Cu}$ [8], Mn [9], Os [10] and Pd [11], have been reported. Furthermore, solid-supported transition metal nanoparticles
(NPs) have gained some interest in development of new catalysts because they are active and reusable catalysts [12-14]. With this purpose in mind, a few researchers have reported that heterogeneous palladium NPs can catalyze aerobic oxidation of aromatic alcohols $[15,16]$.

It is also worth noting that the applications of Pd-based catalysts are not limited to alcohol oxidation. They play important roles in organic synthesis, pharmaceutical chemistry, and polymer science $[17,18]$. Furthermore, they are not limited to heterogeneous catalysis; Pd complexes with various ligands have been synthesized and applied as homogeneous catalysts to obtain high selectivity and efficiency. However, homogeneous Pd catalysts suffer from several problems including difficulty in separation, recovery, and regeneration of the particles and

\footnotetext{
* Corresponding author. E-mail: hojatveisi@yahoo.com DOI: 10.1016/S1872-2067(18)63049-9 | http://www.sciencedirect.com/science/journal/18722067 | Chin. J. Catal., Vol. 39, No. 6, June 2018
} 
resulting pollution of the environment and the products [19]. Heterogeneous Pd catalysts can overcome these limitations efficiently, though they are not as active as homogeneous catalysts due to the disfavored kinetics of biphasic catalytic systems. Therefore, Pd species are usually anchored on a solid support matrix with high specific surface area to increase the number of collisions between Pd particles and the substrates [20-24]. Leaching of Pd during catalysis is another disadvantage of Pd heterogeneous catalysis. To reduce leaching and increase catalytic activity of supported Pd catalysts, solid matrices can be modified chemically with different chelating ligands to improve the interaction of the solid support with $\mathrm{Pd}$ particles [25-27]. Unfortunately, leaching of Pd species from catalyst supports cannot be completely avoided because the interaction between the supports and Pd species weakens under harsh reaction conditions, e.g. high reaction temperature.

This study is an attempt to continue our previous research [28-36] and to develop a new hybrid nanocomposite, which can act as both a reducing agent and a stabilizing agent for immobilization of Pd NPs. For this purpose, $\mathrm{SiO}_{2}$ particles were modified in situ with polydopamine by polymerization of dopamine in tris-buffer solution ( $\mathrm{pH}$ 8.5) under constant stirring. Then, the generated $\mathrm{SiO}_{2}$ /PDA NPs were used to adsorb Pd ions on the PDA layers. Pd ions were immediately reduced to metallic Pd nanoparticles in situ by active catechol and amine groups. The synthesis of the catalyst $\mathrm{SiO}_{2} / \mathrm{PDA} / \mathrm{Pd}$ NPs is depicted in Scheme 1. The synthesized NPs were characterized by Fourier transform infrared spectroscopy (FT-IR), X-ray diffraction (XRD), field-emission scanning electron microscopy (FESEM), energy-dispersive X-ray spectroscopy (EDS), high-resolution transmission electron microscopy (HRTEM), X-ray photoelectron spectroscopy (XPS), and inductively coupled plasma (ICP) techniques. Furthermore, catalytic performance, recyclability and convenience of separation of $\mathrm{SiO}_{2} / \mathrm{PDA} / \mathrm{Pd}$ NPCs were examined by carrying out aerobic oxidation of alcohols to their corresponding carbonyl compounds (Scheme 1).

\section{Experimental}

\subsection{Preparation of $\mathrm{SiO}_{2} / \mathrm{PDA} / \mathrm{Pd} \mathrm{NPS}$}

Silica gel $(1 \mathrm{~g})$ was dispersed in $500 \mathrm{~mL}$ Tris buffer $(10$ mmol/L, pH 8.5), then dopamine (1 g) was added, and the mixture was mechanically stirred for $24 \mathrm{~h}$ at room temperature. After reaction, the $\mathrm{SiO}_{2} / \mathrm{PDA}$ nanoparticles were filtered and washed with deionized water and anhydrous ethanol and dried at $40{ }^{\circ} \mathrm{C}$ to give $\mathrm{SiO}_{2} / \mathrm{PDA}$.

In the next step, the $\mathrm{SiO}_{2} / \mathrm{PDA}$ composite $(0.5 \mathrm{~g})$ was dispersed in $\mathrm{H}_{2} \mathrm{O}(100 \mathrm{~mL})$ by ultrasonic bath for $20 \mathrm{~min}$. Subsequently, a solution of $\mathrm{Na}_{2} \mathrm{PdCl}_{4}(0.02 \mathrm{~g})$ in $20 \mathrm{~mL}$ water was added to the reaction mixture and stirred for $24 \mathrm{~h}$ under reflux conditions. Then, the $\mathrm{SiO}_{2} / \mathrm{PDA} / \mathrm{Pd}$ NPs was separated by centrifuge and washed with $\mathrm{H}_{2} \mathrm{O}$ and acetone respectively to remove the unattached substrates. Scheme 1 depicts the synthetic procedure of $\mathrm{SiO}_{2} / \mathrm{PDA} / \mathrm{Pd}$ NPs. The final nanocatalyst was dried in vacuum at $40{ }^{\circ} \mathrm{C}$. The concentration of palladium was $1.89 \mathrm{wt} \%$ (0.18 $\mathrm{mmol} / \mathrm{g})$, as determined by ICP-AES.

\subsection{Aerobic oxidation of alcohols}

A mixture of $\mathrm{K}_{2} \mathrm{CO}_{3}(1 \mathrm{mmol})$ and the $\mathrm{SiO}_{2} / \mathrm{PDA} / \mathrm{Pd}$ NPs (80 $\mathrm{mg}, 0.5 \mathrm{~mol} \% \mathrm{Pd})$ in toluene $(5 \mathrm{~mL})$ was prepared in a two-necked flask. The flask was evacuated and refilled with pure oxygen. To this solution, the alcohol $(1 \mathrm{mmol}$, in $1 \mathrm{~mL}$ toluene) was injected and the resulting mixture was stirred at $80{ }^{\circ} \mathrm{C}$ in an oxygen atmosphere. After completion of the reac-

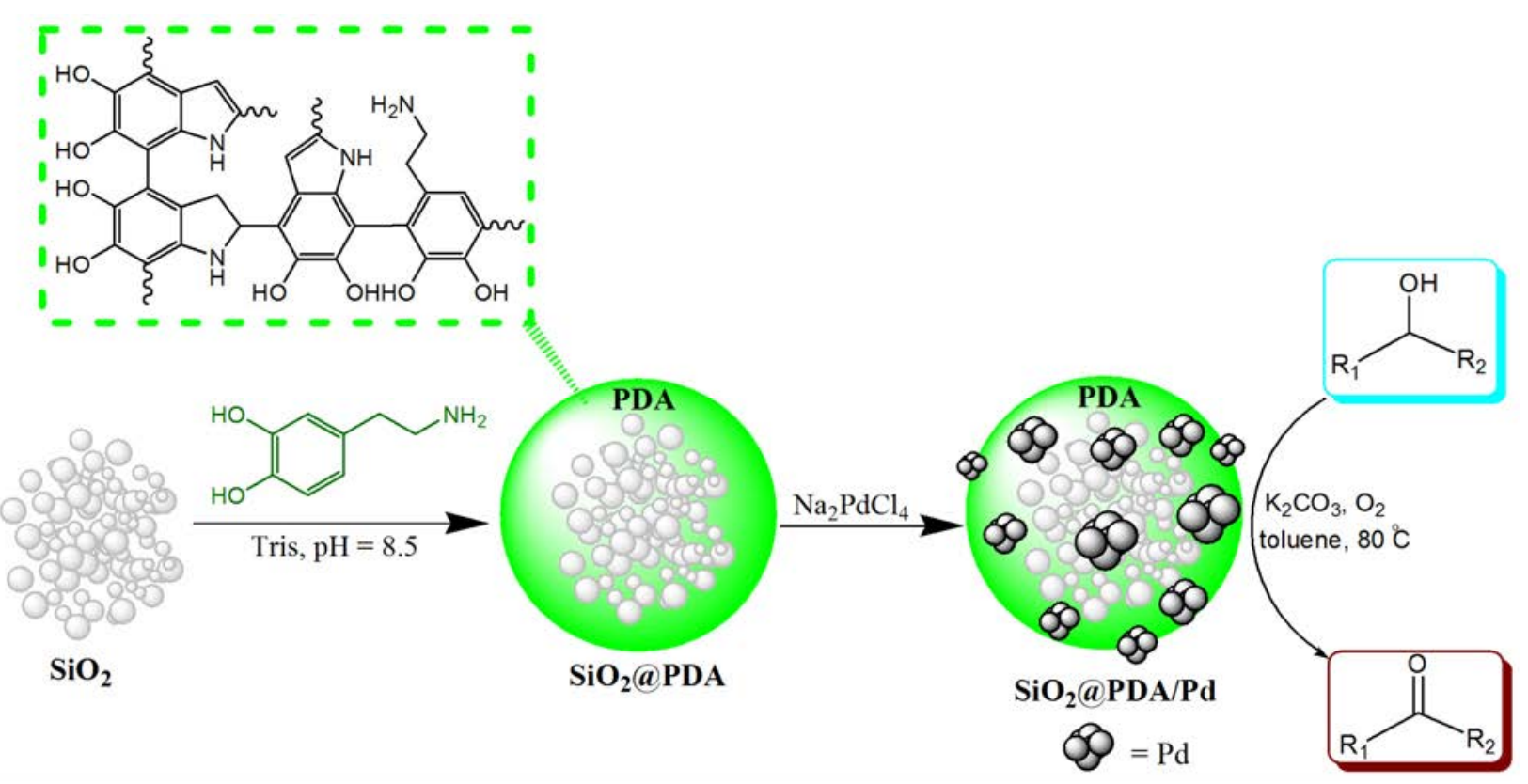

Scheme 1. Preparation ofSiO $2 / \mathrm{PDA} / \mathrm{Pd}$ NPsand its application as a novel heterogeneous nanocatalyst for aerobic oxidation of alcohols. 


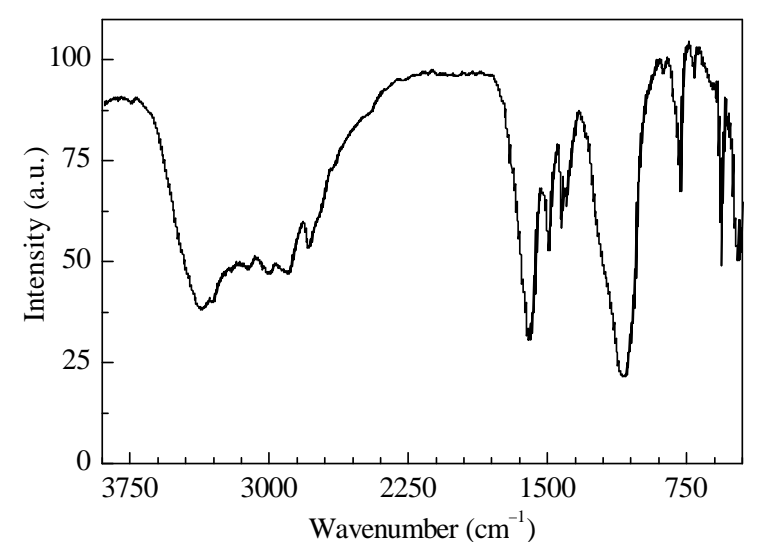

Fig. 1. FT-IR spectrum of $\mathrm{SiO}_{2} / \mathrm{PDA} / \mathrm{Pd}$ NPs.

tion, the reaction mixture was filtered off and the catalyst was rinsed twice with $\mathrm{CH}_{2} \mathrm{Cl}_{2}$ (5 mL). The excess solvent was removed under reduced pressure to give the resultant carbonyl compounds.

\section{Results and discussion}

\subsection{Characterization}

The FT-IR spectrum of $\mathrm{SiO}_{2} / \mathrm{PDA} / \mathrm{Pd}$ NPs (Fig. 1) shows several strong bands in the low-frequency region of 500-1000 $\mathrm{cm}^{-1}$. These bands are attributed to the silica skeleton of the NCs and are in agreement with the silica spectrum. In addition,

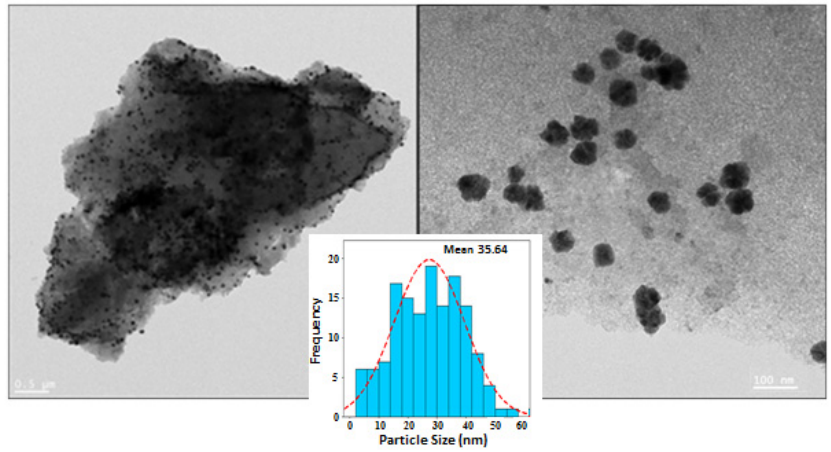

Fig. 2. HRTEM images of $\mathrm{SiO}_{2} / \mathrm{PDA} / \mathrm{Pd}$ NPs and its particle size distribution.

Si-O and O-H characteristic bands appear at 1080 and 3200 to $3400 \mathrm{~cm}^{-1}$, respectively [37]. The peaks located at 3400, 2935, 1487, and $1450 \mathrm{~cm}^{-1}$ correspond to $\mathrm{O}-\mathrm{H}, \mathrm{C}-\mathrm{H}, \mathrm{C}=\mathrm{C}$, and $\mathrm{C}-\mathrm{N}$ stretching modes of polydopamine groups on silica matrix, respectively [38]. The 1599 and $1412 \mathrm{~cm}^{-1}$ peaks can be assigned to vibration of the benzene rings [38]. These peaks are a hallmark of successful PDA polymer immobilization on silica gel surface via both physisorption and chemisorption. This was further verified by HRTEM images, which were used to investigate the nanostructure of $\mathrm{SiO}_{2} / \mathrm{PDA} / \mathrm{Pd} \mathrm{NPs}$.

As Fig. 2 illustrates, an apparent PDA coating has immobilized the silica particles. This encapsulation shell can reduce Pd ions and cap the NPs. HRTEM imaging identified Pd NPs with nearly spherical morphologies. These particles were relatively

(a)
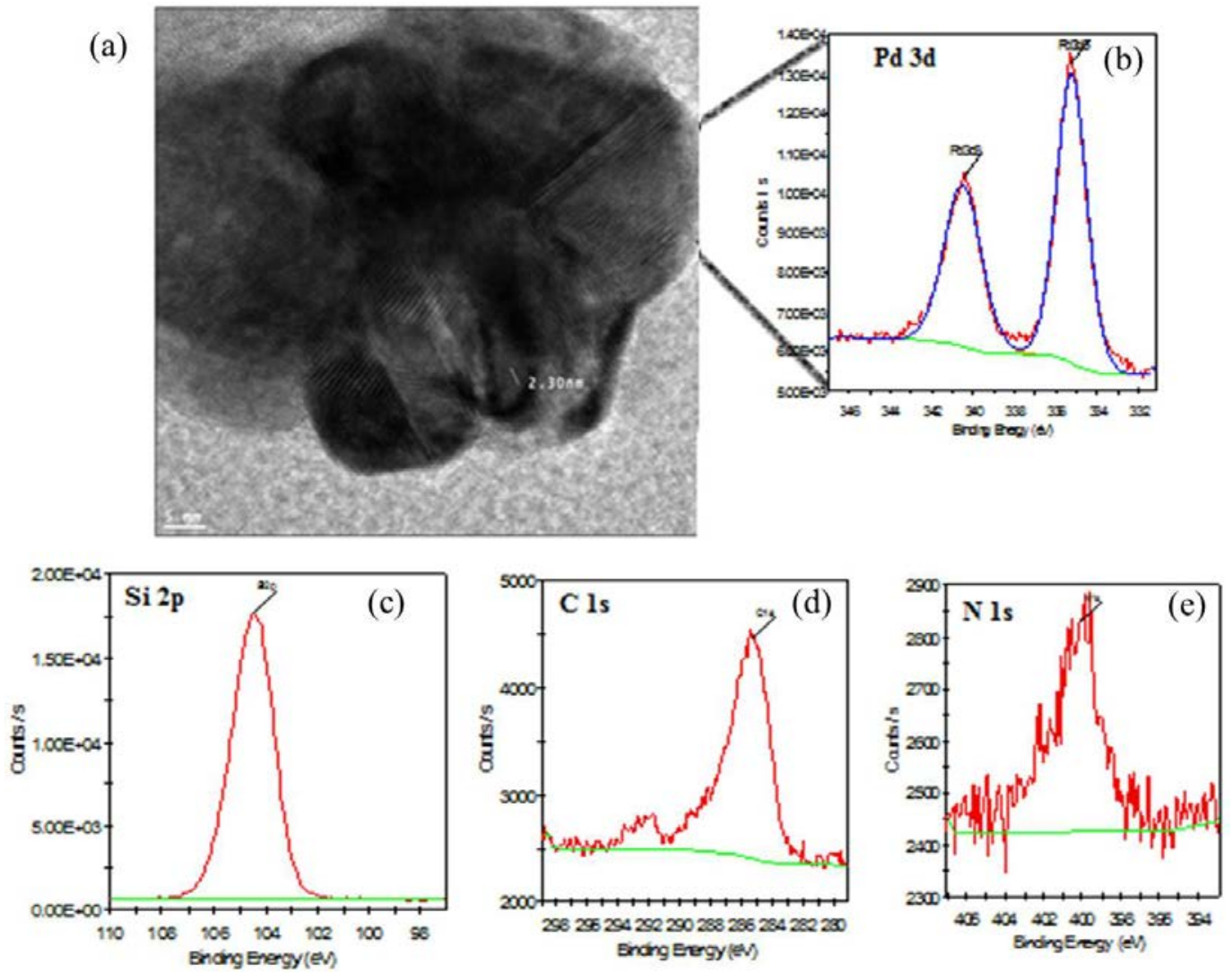

Fig. 3. HRTEM image (a) and XPS spectrum of the $\mathrm{SiO}_{2} / \mathrm{PDA} / \mathrm{Pd}$ in the $\mathrm{Pd} 3 d(\mathrm{~b}), \mathrm{Si} 2 p(\mathrm{c}), \mathrm{C} 1 s(\mathrm{~d})$, and $\mathrm{N} 1 s$ (e) regions. 
well dispersed and were $30-40 \mathrm{~nm}$ in diameter. The histogram clearly defined the average hydrodynamic size of the Pd NPs as $35.64 \mathrm{~nm}$.

In order to obtain exact details about the oxidation state of the $\mathrm{Pd}$ species in $\mathrm{SiO}_{2} / \mathrm{PDA} / \mathrm{Pd}$ NPs, XPS was performed in the $\mathrm{Pd} 3 d$ region (Fig. 3). The 335.8 and $340.9 \mathrm{eV}$ peaks in the $\mathrm{Pd}$ XPS spectrum are associated with the $\mathrm{Pd} 3 d_{5 / 2}$ and $\mathrm{Pd} 3 d_{3 / 2}$ binding energies, respectively. These binding energy values are consistent with reference metallic $\mathrm{Pd}\left(\mathrm{Pd}^{0}\right)$ reported data [39], showing that an $\mathrm{SiO}_{2} / \mathrm{PDA} / \mathrm{Pd}^{0} \mathrm{NPs}$ hybrid has been generated successfully. The characteristic peaks related to carbon (C 1s), nitrogen ( $\mathrm{N} 1 s$ ), and silica ( $\mathrm{Si} 2 p$ ) are visible in the XPS elemental survey.

Size and morphology of the $\mathrm{SiO}_{2} / \mathrm{PDA} / \mathrm{Pd}$ NPs were also investigated by SEM. The FESEM image of $\mathrm{SiO}_{2} / \mathrm{PDA} / \mathrm{Pd}$ NPs revealed that the catalyst's size was is in the nanometer range and the formed particles were quasi-spherical NPs (Fig. 4). The existence of the PDA shell and Pd on the surface of the silica gel was also confirmed through the coupling of an EDX detector to an FESEM instrument. In this way, $\mathrm{Si}, \mathrm{C}, \mathrm{O}$, and $\mathrm{Pd}$ were detected in the sample (Fig. 4). Fig. 4 also displays the related elemental maps for the synthesized nanocatalyst, showing that Si, O, C, N, and Pd are present homogeneously throughout the sample which confirms uniformity of the prepared sample.

The XRD pattern of the synthesized palladium NPs (Fig. 5) shows several intense peaks at $2 \theta$ values of $39.9^{\circ}, 46.3^{\circ}$, and

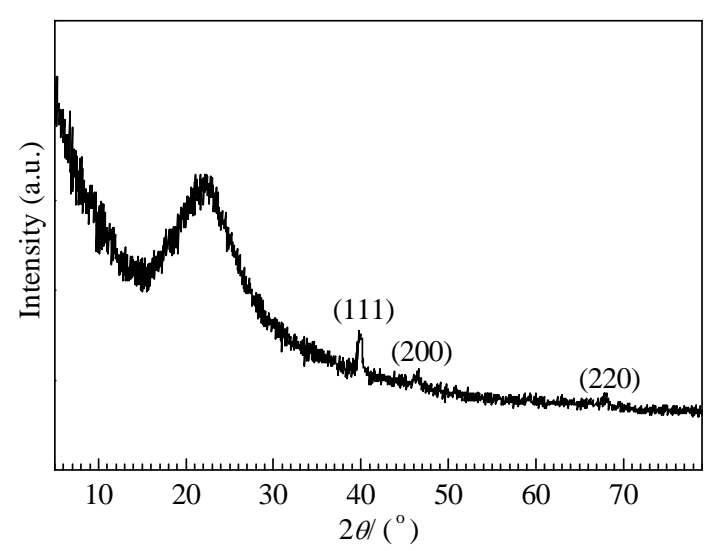

Fig. 5. XRD pattern of $\mathrm{SiO}_{2} / \mathrm{PDA} / \mathrm{Pd}$.

$67.8^{\circ}$, corresponding to the (111), (200), and (220) Bragg reflections, respectively. Comparison of the XRD pattern with JCPDS standard (\#05-0681) confirmed correct synthesis and cubic $(f c c)$ crystal structure of the PdNPs. Such a unit cell structure is in agreement with earlier reports [40].

Activity of the proposed $\mathrm{SiO}_{2} / \mathrm{PDA} / \mathrm{Pd} \mathrm{NPs}$, as a novel heterogeneous nanocatalyst, was probed in aerobic oxidation of alcohols to the corresponding carbonyl compounds. First, the oxidation of para-methylbenzyl alcohol was evaluatedusing different amounts of the catalyst in an oxygen atmosphere. The

(a)
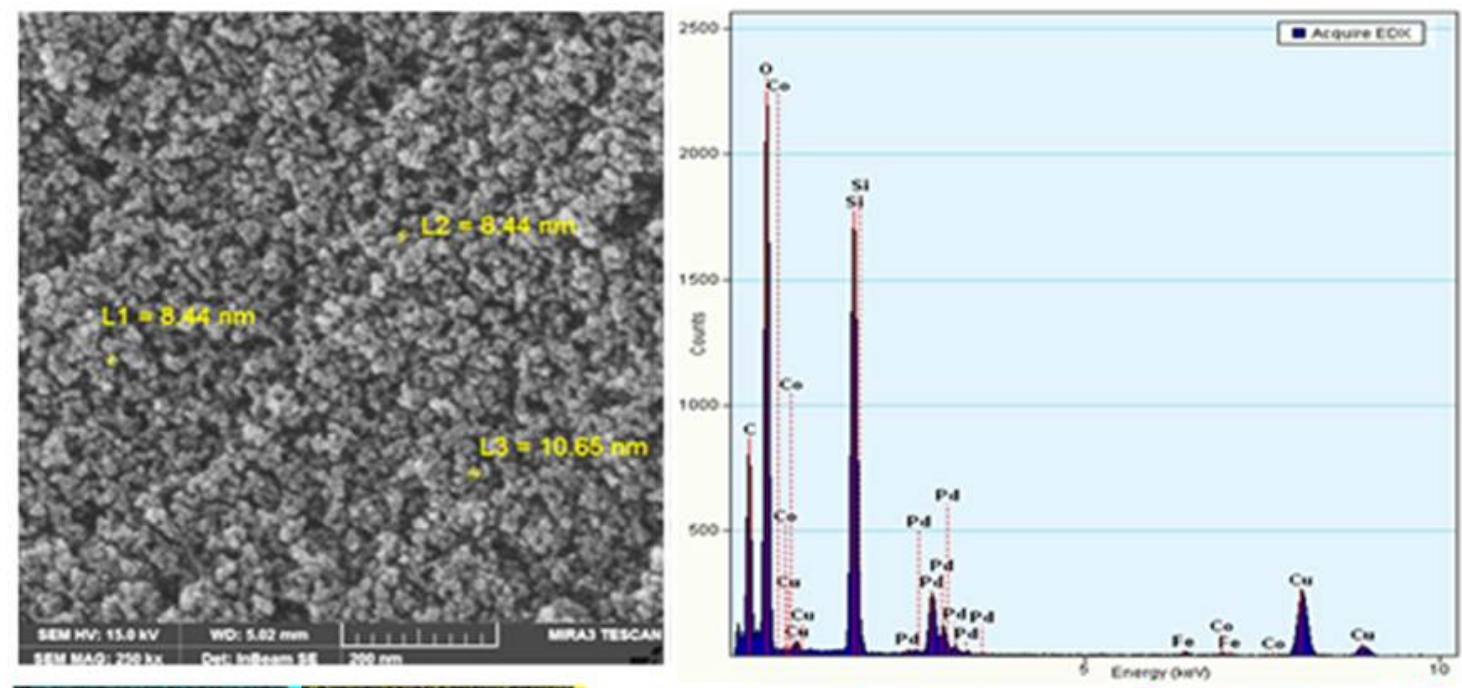

(b)
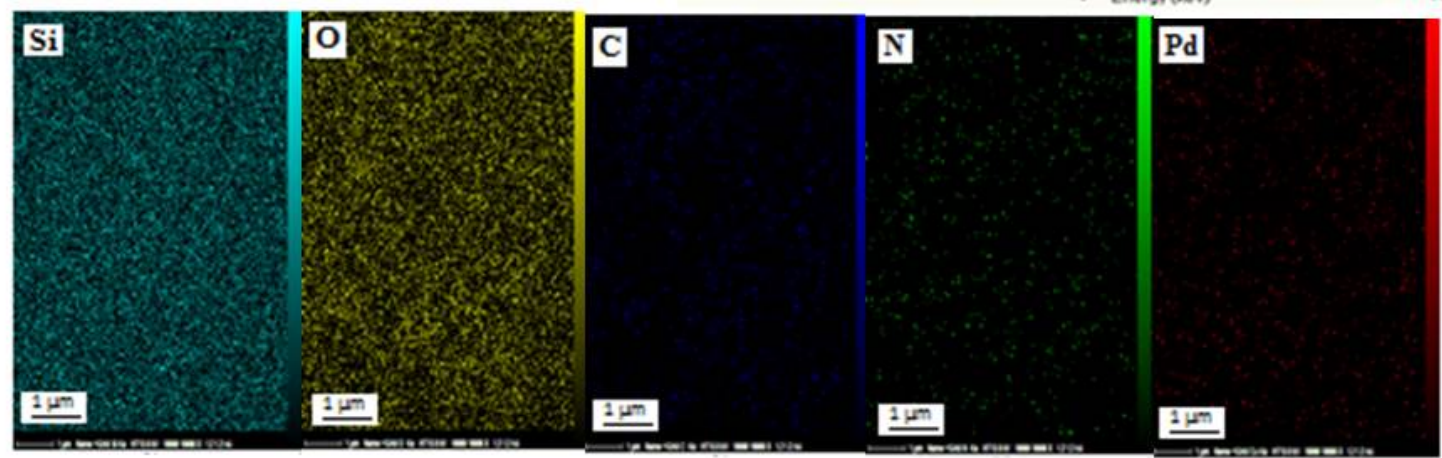

Fig. 4. FESEM image (a), EDX spectrum (b) of $\mathrm{SiO}_{2} / \mathrm{PDA} / \mathrm{Pd}$ and elemental maps of $\mathrm{Si}, \mathrm{O}, \mathrm{C}, \mathrm{N}$, and $\mathrm{Pd}$ atoms in the catalyst. 
Table 1

Optimization of reaction conditions in oxidation of para-methylbenzylalcohol. ${ }^{\text {a }}$

\begin{tabular}{|c|c|c|c|c|c|c|}
\hline Entry & $\begin{array}{c}\text { Catalyst amount } \\
(\mathrm{mol} \%)\end{array}$ & $\begin{array}{c} \\
\left({ }^{\circ} \mathrm{C}\right) \\
\end{array}$ & Base & $\begin{array}{c}\text { Time } \\
\text { (h) }\end{array}$ & $\begin{array}{c}\text { Yield }^{\mathrm{b}} \\
(\%) \\
\end{array}$ & $\begin{array}{l}\text { TOF c } \\
\left(\mathrm{h}^{-1}\right)\end{array}$ \\
\hline 1 & - & 80 & - & 24 & NR & 0.0 \\
\hline 2 & 0.1 & 80 & - & 18 & 10 & 5.6 \\
\hline 3 & 0.2 & 80 & - & 12 & 15 & 6.2 \\
\hline 4 & 0.3 & 80 & - & 12 & 25 & 6.9 \\
\hline 5 & 0.4 & 80 & - & 12 & 35 & 7.3 \\
\hline 6 & 0.4 & 80 & $\mathrm{~K}_{2} \mathrm{CO}_{3}$ & 12 & 72 & 15.0 \\
\hline 7 & 0.5 & 80 & $\mathrm{~K}_{2} \mathrm{CO}_{3}$ & 12 & 95 & 15.8 \\
\hline 8 & 0.5 & 80 & $\mathrm{Et}_{3} \mathrm{~N}$ & 12 & 75 & 12.5 \\
\hline 9 & 1.0 & 80 & $\mathrm{~K}_{2} \mathrm{CO}_{3}$ & 12 & 95 & 7.9 \\
\hline 10 & 0.5 & 25 & $\mathrm{~K}_{2} \mathrm{CO}_{3}$ & 12 & 45 & 7.5 \\
\hline
\end{tabular}

a Reactions conditions: para-methylbenzyl alcohol (1 mmol), $\mathrm{SiO}_{2} / \mathrm{PDA} /$ Pd NPs, base (2 mmol), toluene $(5 \mathrm{~mL})$ at 80 or $25^{\circ} \mathrm{C}$ under an oxygen atmosphere.

b Isolated yield.

c Turnover frequencies $($ TOF $=($ Yield/Time $) /$ Amount of catalyst $(\mathrm{mol}))$.

expected oxidation did not take place in the absence of Pd (Table 1, entry 1). The desired product was obtained in low yield (only 35\%) in the absence of an appropriate base, when 0.4 mol\% of the catalyst were employed for $12 \mathrm{~h}$, at $80{ }^{\circ} \mathrm{C}$ (Table 1 , entries 1-4). However, when $\mathrm{K}_{2} \mathrm{CO}_{3}$ was used as a base, the reaction proceeded with $95 \%$ yield of the target product, under the same conditions (Table 1, entry 7). Therefore, presence of the base significantly enhanced the activity of the catalyst. When 0.5 mol\% catalyst was used with $\mathrm{K}_{2} \mathrm{CO}_{3}$ as the base at 80 ${ }^{\circ} \mathrm{C}$, the corresponding product was obtained exclusively with very high turnover frequencies (TOF) (Table 1, entry 7).

Further experiments were conducted on the oxidation of various substituted primary and secondary benzyl alcohols to test the substrate scope of the reaction. The results indicate that both primary and secondary benzyl alcohols can be efficiently oxidized to give the corresponding aldehydes and ketones in high yields. It can be seen that secondary benzyl alcohols are reactive towards oxidation and the desired products can be obtained in excellent yields (Table 2, entries 5 and 6). The tested primary benzyl alcohols, which possess electron-donating and electron-withdrawing functional groups, give high yields (Table 2, entries 2 and 3). Moreover, conversion of allylic alcohols, e.g. cinnamyl alcohol (Table 2, entry 7), to the corresponding aldehydes was completed within $12 \mathrm{~h}$. During the performed reactions, $\mathrm{C}=\mathrm{C}$ double bonds of the substrates remained intact and no intra-molecular hydrogen transfer occurred over $\mathrm{SiO}_{2} / \mathrm{PDA} / \mathrm{Pd} \mathrm{NPs}$.

Since reusability of catalysts is essential for commercial applications, recovery and reusability of the title catalyst was investigated for aerobic oxidation of para-methoxybenzyl alcohol, under the aforementioned conditions. At the end of each reaction cycle, the solid catalyst was filtered, washed with acetone and water, and then dried and reused. This process was repeated 6 times; the catalyst was found to retain its catalytic activity in allthe cycles (Fig. 6). The reaction was performed
Table 2

Aerobic oxidation of various alcohols catalyzed by $\mathrm{SiO}_{2} / \mathrm{PDA} / \mathrm{PdNPs}$. $^{\text {a }}$

\begin{tabular}{lccc}
\hline Entry & $\mathrm{R}_{1}$ & $\mathrm{R}_{2}$ & Yield $^{\mathrm{b}}(\%)$ \\
\hline 1 & $\mathrm{Ph}-$ & $\mathrm{H}$ & 96 \\
2 & $4-\mathrm{OMe}-\mathrm{Ph}-$ & $\mathrm{H}$ & 92 \\
3 & $4-\mathrm{Me}-\mathrm{Ph}-$ & $\mathrm{H}$ & 95 \\
4 & $4-\mathrm{NO}_{2}-\mathrm{Ph}-$ & $\mathrm{H}$ & 85 \\
5 & $\mathrm{Ph}-$ & $\mathrm{CH}_{3}$ & 90 \\
6 & $\mathrm{Ph}-$ & $\mathrm{Ph}^{-}$ & 90 \\
7 & $\mathrm{Ph}-\mathrm{CH}=\mathrm{CH}-$ & $\mathrm{H}$ & 85 \\
\hline
\end{tabular}

a Reaction conditions: alcohol ( $1 \mathrm{mmol}), \mathrm{SiO}_{2} / \mathrm{PDA} / \mathrm{Pd} \mathrm{NPs}(80 \mathrm{mg}, 0.5$ mol\%), $\mathrm{K}_{2} \mathrm{CO}_{3}(2 \mathrm{mmol})$, toluene $(5 \mathrm{~mL})$ at $80{ }^{\circ} \mathrm{C}$ under an oxygen atmosphere.

b Isolated yield.

under the same conditions with constant reaction duration in each run. No palladium black was formed in the reaction mixture even after using the catalyst 6 times. This observation proves that there was negligible Pd leaching from the polymeric supported system, which promotes reusability of the PdNPs. To determine the exact extent of Pd leaching, ICP-AAS analysis was used, which detected only $0.5 \%$ Pd loss from the NPs after the $6^{\text {th }}$ run. Consequently, the PdNPs remained active in repetitive catalytic cycles due to excellent stabilization of Pd species by the PDA layers.

Lastly, catalyst heterogeneity for oxidation reactions was examined by hot filtration. To perform this test, $\mathrm{SiO}_{2} / \mathrm{PDA} / \mathrm{Pd}$ NPs were applied to the oxidation of para-methoxybenzyl alcohol under the same conditions as the previous experiments. After $5 \mathrm{~h}$ of the reaction, i.e. when $55 \%$ yield was achieved, the NPs were removed from the reaction medium and the reaction was traced without the solid catalyst for another $5 \mathrm{~h}$. In the absence of the catalyst, no further increase in yield could be observed, which confirmedthe heterogeneous property of the NPs. The FESEM and HRTEM images (Fig. 7) of the catalyst after the $6^{\text {th }}$ run indicated the preservation of the catalyst's nanostructure.

The oxidation of benzyl alcohol was performed to compare the synthesized $\mathrm{SiO}_{2} / \mathrm{PDA} / \mathrm{Pd}$ NPs efficiency with previously reported catalysts (Table 3). From Table 3, it is apparent that the current catalyst gave greater conversion and yield than other listed systems.

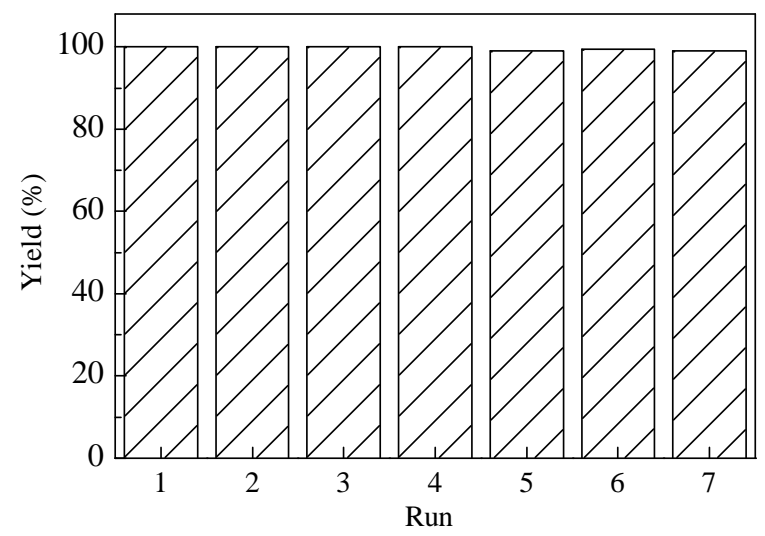

Fig. 6. The recycling of $\mathrm{SiO}_{2} / \mathrm{PDA} / \mathrm{Pd}$ NPs for the aerobic oxidation of para-methoxylbenzyl alcohol. 


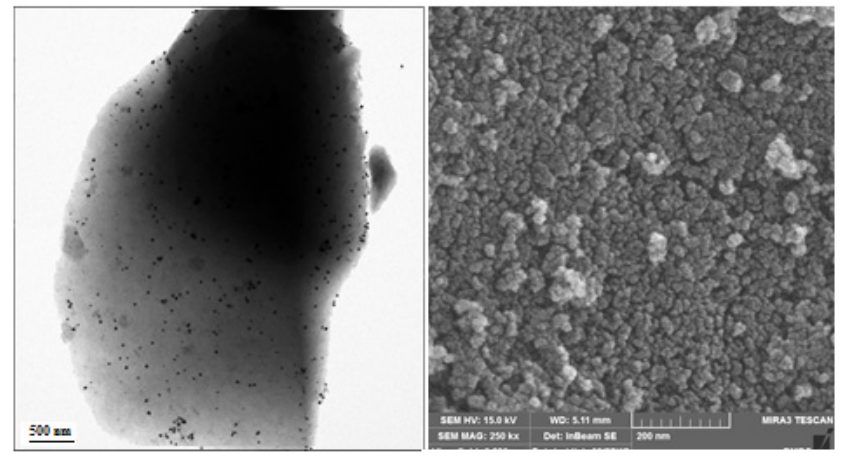

Fig. 7. HRTEM (a) and FESEM (b) images of reused catalyst after the $6^{\text {th }}$ run.

\section{Table 3}

Comparison of efficiency of $\mathrm{SiO}_{2} / \mathrm{PDA} / \mathrm{Pd} \mathrm{NPs}$ with some reported catalysts for the oxidation reaction of benzyl alcohol.

\begin{tabular}{|c|c|c|c|c|}
\hline Entry & Reaction conditions & $\begin{array}{c}\text { Time } \\
\text { (h) }\end{array}$ & $\begin{array}{c}\text { Yield } \\
(\%)\end{array}$ & Ref. \\
\hline 1 & $\mathrm{SiO}_{2} / \mathrm{PDA} / \mathrm{Pd} \mathrm{NPs}$, toluene, $\mathrm{K}_{2} \mathrm{CO}_{3}, 80^{\circ} \mathrm{C}$ & 12 & 96 & This work \\
\hline 2 & $\mathrm{Pd} / \mathrm{MagSBA}$, solvent-free, $80^{\circ} \mathrm{C}$ & 9 & 71 & {$[30]$} \\
\hline 3 & $\mathrm{Au}-\mathrm{Pd} / \mathrm{SBA}$, solvent-free, $160^{\circ} \mathrm{C}$ & 4 & 67.2 & {$[31]$} \\
\hline 4 & $\mathrm{Pd} / \mathrm{NMC}$, solvent-free, $160^{\circ} \mathrm{C}$ & 1 & 59.8 & {$[32]$} \\
\hline 5 & Co-NG, DMF, $130^{\circ} \mathrm{C}$ & 5 & 92.4 & [33] \\
\hline 6 & $\mathrm{RMC}-\mathrm{Au}$, toluene, $\mathrm{K}_{2} \mathrm{CO}_{3}, 130^{\circ} \mathrm{C}$ & 3 & 85 & {$[34]$} \\
\hline 7 & $\mathrm{Fe}_{3} \mathrm{O}_{4} / \mathrm{Cys}-\mathrm{Pd}$, solvent-free, $50^{\circ} \mathrm{C}$ & 1.5 & 85 & {$[35]$} \\
\hline 8 & $\mathrm{Pd} / \mathrm{CeO}_{2}$, solvent-free, $160^{\circ} \mathrm{C}$ & 1 & 20.8 & {$[36]$} \\
\hline 9 & $\mathrm{Au}-\mathrm{Pd} / \mathrm{TiO}_{2}$, solvent-free, $160^{\circ} \mathrm{C}$ & 1.4 & 34.2 & [37] \\
\hline
\end{tabular}

\section{Conclusions}

Herein we have devised a simple, efficient, and feasible protocol for the in situ synthesis of Pd NPs immobilized on polydopamine coated-silica gel [ $\left.\mathrm{SiO}_{2} / \mathrm{PDA} / \mathrm{Pd} \mathrm{NPs}\right]$, as a novel and reusable catalyst. Various properties of the catalyst are clarified by HRTEM, FT-IR, FESEM, XPS, XRD, ICP and EDS analysis techniques. Application of the NPs as a heterogeneous nanocatalyst revealed good catalytic efficiency in aerobic oxidation of alcohols under convenient conditions. Importantly, the catalyst can be reused in six consecutive catalytic cycles without any noticeable decline in catalytic activity. These advantages suggest that the developed protocol is a highly valuable method from environmental and synthetic perspectives.

\section{Acknowledgments}

We are thankful to Payame Noor University (PNU) for partial support of this work.

\section{References}

[1] R. A. Sheldon, I. W. C. E. Arends, A. Dijksman, Catal. Today, 2000, $57,157-166$.

[2] R. A. Sheldon, J. K. Kochi, Metal-Catalyzed Oxidations of Organic Compounds, Academic Press, New York, 1981.

[3] T. Mallat, A. Baiker, Chem. Rev., 2004, 104, 3037-3058.

[4] I. E. Marko, P. R. Giles, M. Tsukazaki, I. Chelle-Regnaut, A. Gautier, R. Dumeunier, F. Philippart, K. Doda, J. L. Mutonkole, S. M. Brown, C. J. Urch, Adv. Inorg. Chem., 2004, 56, 211-240.
[5] S. E. Martin, D. F. Suarez, Tetrahedron Lett., 2002, 43, 4475-4479.

[6] K. Yamaguchi, N. Mizuno, Angew. Chem. Int. Ed., 2002, 41, 4538-4542.

[7] V. B. Sharma, S. L. Jain, B. Sain, Tetrahedron Lett., 2003, 44, 383-386.

[8] P. Gamez, I. W. C. E. Arends, J. Reedijk, R. A. Sheldon, Chem. Commun., 2003, 2414-2415.

[9] Y. C. Son, V. D. Makwana, A. R. Howell, S. L. Suib, Angew. Chem. Int. Ed., 2001, 40, 4280-4283.

[10] P. A. Shapley, N. J. Zhang, J. L. Allen, D. H. Pool, H. C. Liang, J. Am. Chem. Soc., 2000, 122, 1079-1091.

[11] U. R. Pillai, E. Sahle-Demessie, Green Chem., 2004, 6, 161-165.

[12] A. Roucoux, J. Schulz, H. Patin, Chem. Rev., 2002, 102, 3757-3778.

[13] S. Ikegami, H. Harmamoto, Chem. Rev., 2009, 109, 583-593.

[14] H. Veisi, M. Ghadermazi, A. Naderi, Appl. Organomet. Chem., 2016, 30, 341-345.

[15] B. Karimi, S. Abedi, J. H. Clark, V. Budarin, Angew. Chem. Int. Ed., 2006, 45, 4776-4779.

[16] H. Veisi, D. Kordestani, S. Sajjadifar, M. Hamelian, Iran. Chem. Commun., 2014, 2, 27-33.

[17] N. T. S. Phan, M. Van Der Sluys, C. W. Jones, Adv. Synth. Catal., 2006, 348, 609-679.

[18] D. Astruc, Inorg. Chem., 2007, 46, 1884-1894.

[19] T. N. Glasnov, S. Findenig, C. O. Kappe, Chem. Eur. J., 2009, 15, 1001-1010.

[20] R. J. White, R. Luque, V. L. Budarin, J. H. Clark, D. J. Macquarrie, Chem. Soc. Rev., 2009, 38, 481-494.

[21] F. Durap, Ö. Metīn, Turk. J. Chem., 2015, 39, 1247-1256.

[22] G. W. Wang, D. Kundu, H. Uyama, J. Colloid Interface Sci., 2015, 451, 184-188.

[23] T. Barakat, J. C. Rooke, M. Franco, R. Cousin, J. F. Lamonier, J. M. Giraudon, B. L. Su, S. Siffert, Eur. J. Inorg. Chem., 2012, 2012, 2812-2818.

[24] B. Tamami, R. Nowroozi Dodeji, S. Ghasemi, Turk. J. Chem., 2015, $39,880-885$.

[25] S. Sharma, N. Rajesh, Chem. Eng. J., 2016, 283, 999-1008.

[26] F. Farjadian, M. Hosseini, S. Ghasemi, B. Tamami, RSC Adv., 2015, 5, 79976-79987.

[27] H. Veisi, M. Hamelian, S. Hemmati, J. Mol. Catal. A, 2014, 395, 25-33.

[28] H. Veisi, J. Gholami, H. Ueda, P. Mohammadi, M. Noroozi, J. Mol. Catal. A, 2015, 396, 216-223.

[29] H. Veisi, M. Hamelian, S. Hemmati, J. Mol. Catal. A, 2014, 395, 25-33.

[30] H. Veisi, A. Sedrpoushan, S. Hemmati, Appl. Organomet. Chem., 2015, 29, 825-828.

[31] H. Veisi, A. R. Faraji, S.Hemmati, A. Gil, Appl. Organomet. Chem., 2015, 29, 517-523.

[32] H. Veisi, A. Rashtiani, V. Barjasteh, Appl. Organomet. Chem., 2016, 30, 231-235.

[33] F. Bonyasi, M. Hekmati, H. Veisi, J. Colloid. Interface Sci., 2017, 496, 177-187.

[34] H. Veisi, R. Masti, D. Kordestani, M. Safaei, O. Sahin, J. Mol. Catal. A, 2014, 385, 61-67.

[35] H. Veisi, S. Hemmati, H. Javaheri, Tetrahedron Lett., 2017, 58, 3155-3159.

[36] B. Abbás Khakiani, K. Pourshamsian, H. Veisi, Appl. Organomet. Chem., 2015, 29, 259-265.

[37] H. Veisi. A. Sedrpoushan, A. R. Faraji, M. Heidari, S. Hemmti, B. Fatahi, RSC Adv., 2015, 86, 70498-70498.

[38] Z. M. Rao, T. H. Wu, S. Y. Peng, Acta Phys. Chim. Sin., 1995, 11, 395-402. 


\title{
Graphical Abstract
}

Chin. J. Catal., 2018, 39: 1044-1050 doi: 10.1016/S1872-2067(18)63049-9

Facile in-situ synthesis and deposition of monodisperse palladium nanoparticles on polydopamine-functionalized silica gel as a heterogeneous and recyclable nanocatalyst for aerobic oxidation of alcohols

Hojat Veisi *, Ahmad Nikseresht, Shahin Mohammadi, Saba Hemmati

Payame Noor University, Iran

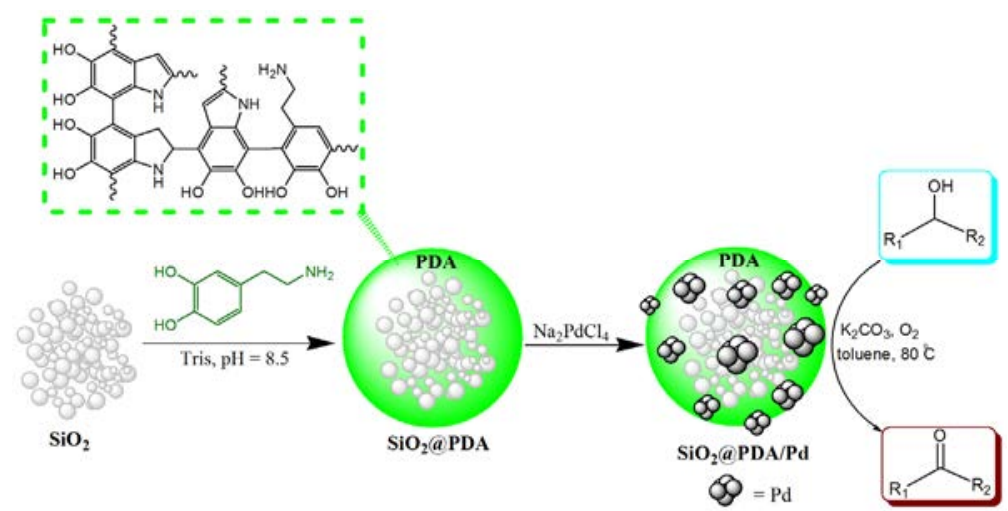

This study described a protocol for in-situ synthesis of Pd nanoparticles immobilized on polydopamine coated-silica gel as a novel nanocatalyst for aerobic oxidation of alcohols.

[39] F. Heidari, M. Hekmati, H. Veisi, J. Colloid Interface Sci., 2017, 501, 175-184.

[40] S. Lebaschi, M. Hekmati, H. Veisi, J. Colloid Interface Sci., 2017, 485, 223-231.

[41] Y. Y. Li, J. L. Huang, X. J. Hu, F. L. Y. Lam, W. J. Wang, R. Luque, J. Mol. Catal. A, 2016, 425, 61-67.

[42] Y. T. Chen, H. P. Wang, C. J. Liu, Z. Y. Zeng, H. Zhang, C. M. Zhou, X. L. Jia, Y. H. Yang, J. Catal., 2012, 289, 105-117.

[43] B. Wang, M. Lin, T. P. Ang, J. Chang, Y. H. Yang, A. Borgna, Catal. Commun., 2012, 25, 96-101.
[44] M. Li, S. J. Wu, X. Y. Yang, J. Hu, L. Peng, L. Bai, Q. S. Huo, J. Q. Guan, Appl. Catal. A, 2017, 543, 61-66.

[45] A. A. S. Oliveira, D. S. Costa, I. F. Teixeira, L. A. Parreira, L. Menini, E. V. Gusevskaya, F. C. C. Moura, Catal. Today, 2017, 289, 89-95.

[46] F. Zamani, S. M. Hosseini, Catal. Commun., 2014, 43, 164-168.

[47] Y. T. Chen, H. J. Zheng, Z. Guo, C. M. Zhou, C. A. Wang, A. Borgna, Y. H. Yang, J. Catal., 2011, 283, 34-44.

[48] E. H. Cao, M. Sankar, E. Nowicka, Q. He, M. Morad, P. J. Miedziak, S. H. Taylor, D. W. Knight, D. Bethell, C. J. Kiely, A. Gavriilidis, G. J. Hutchings, Catal. Today, 2013, 203, 146-152.

\section{聚多巴胺功能化硅胶沉积单分散Pd纳米粒子的简易原位合成及用作醇需氧 氧化反应的多相可循环使用的纳米催化剂}

\author{
Hojat Veisi ${ }^{*}$, Ahmad Nikseresht, Shahin Mohammadi, Saba Hemmati \\ 帕亚莫·努尔大学化学系, 德黑兰, 伊朗
}

\begin{abstract}
摘要: 本文报道了一种不使用任何稳定剂或还原剂, 原位合成硅胶/聚多巴胺复合物 $\left(\mathrm{SiO}_{2} / \mathrm{PDA}\right)$ 负载的Pd纳米颗粒 $(\mathrm{Pd} \mathrm{NPs})$ 的简易方法. 该方法先将PDA涂覆的 $\mathrm{SiO}_{2}$ 颗粒浸在Pd镀液中, 然后利用PDA中含 $\mathrm{N}$ 基团的还原能力将Pd物种原位还原为纳 米簇合物. 并采用高分辨透射电镜、前场扫描电镜、能量散射谱、X射线衍射、X射线光电子能谱、诱导耦合等离子体和 红外光谱等手段对所得纳米复合物的结构、形貌和物化性质进行了表征. 被PDA基团针合的Pd NPs具有显著的小颗粒 $(30-40 \mathrm{~nm})$ 特性. 作为一个可循环使用的纳米催化剂, $\mathrm{SiO}_{2} / \mathrm{PDA} / \mathrm{Pd} \mathrm{NPs}$ 在醇的需氧氧化反应中表现出高活性. 另外, 催化 剂经回收和多次重复使用时未出现明显的失活.
\end{abstract}

关键词: 硅胶; 聚多巴胺; 钯纳米颗粒; 氧化; 醇

收稿日期: 2017-12-29. 接受日期: 2018-02-21. 出版日期: 2018-06-05.

*通讯联系人. 电子信箱: hojatveisi@yahoo.com

本文的电子版全文由Elsevier出版社在ScienceDirect上出版(http://www.sciencedirect.com/science/journal/18722067). 